\title{
Radioactive Effluents in Savannah River - Summary Report for 1997
}

by

W. G. Winn

Westinghouse Savannah River Company

Savannah River Site

Aiken, South Carolina 29808

This paper was prepared in connection with work done under the above contract number with the U. S. Department of Energy. By acceptance of this paper, the publisher and/or recipient acknowledges the U. S. Government's right to retain a nonexclusive, royalty-free license in and to any copyright covering this paper, along with the right to reproduce and to authorize others to reproduce all or part of the copyrighted paper. 


\section{DISCLAIMER}

This report was prepared as an account of work sponsored by an agency of:the United States Government. Neither the United States Government nor any agency thereof, nor any of their employees, makes any warranty, express or implied, or assumes any legal liability or. -responsibility for the accuracy, completeness, or usefuliness of any information, apparatus, product, or process disclosed, or represents that its use would not infringe privately owned rights. Reference herein to any specific commercial product, process, or service by trade name, trademark, manufacturer, or otherwise does not necessarily constitute or imply its endorsement. recommendation, or favoring by the United States Government ar any agency thereof. The views and opinions of authors expressed herein do not necessarily state or reflect those of the United States Government or any agency thereof.

This report has been reproduced directly from the best available copy.

Available to DOE and DOE contractors from the Office of Scientific and Technical Information, P.O. Box 62, Oak Ridge, TN 37831; prices available from (615) 576-8401.

Available to the public from the National Technical. Information Service, U.S. Department of Commerce, 5285 Port Royal Road, Springfield, VA 22161. 


\section{DISCLAIMER}

Portions of this document may be illegible electronic image products. Images are produced from the best available original document. 


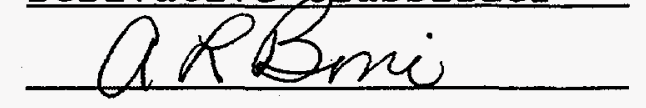

Keywords

Plant Vogtle Savannah River Effluent Releases Isotopic Activities River Samples Gamma Spectrometry: HPGe Detectors NaI(TI) Detectors

\section{Lifetime Retention}

$$
\begin{array}{ll}
\text { CC: SR-DOE } & \text { A.C. Doswel1, 703-47A } \\
& \text { E.C. Goodson, 703-46A } \\
& \text { K.L. Hooker, 703-A } \\
& \text { D.P. Ryan, 703-46A }
\end{array}
$$

SRS

P.T. Deason, 773-A

D.B. Moore-Shedrow, 773A

J.B. Gladden, 773-42A

A.L. Boni, 773-A

R.P. Addis, 773-A

W.H. Carlton, 773-A

W.A. Emel, 735-A

R.A. Sigg, 773-41A

K.J. Hofstetter, 735-A

K.W. MacMurdo, 735-A

D.W. Hayes, 735-A

D.M. Beals, 735-A

J.R. Cadieux, 735-A

S.H. Reboul, 735-A.

K. Chen, 773-A

G.T. Jannik, 773-A

D.L. Dunn, 773-42A

F. B. Davis, 730-4B

D.T. Bignel1, 742-A

M.D. Dukes, 742-A

J.D. Heffner, 735-16A

R. Lorenz, 735-16A

R.H. Young, 735-16A

P.D. Fledderman, 735-11A

B.C. Marcy, 773-42A

STI File copies

(4)

TO: J.E. HALVERSON

FROM: W.G. WINN $20 \mathrm{~h}$

July 7,1997

\section{Radioactive Effluents in Savannah River summary Report for 1997 (U)}

(Cover Sheet) 
CC: Distribution on Cover sheet

TO: J.E. HALVERSON

July 7,1997

FROM: W.G. WINN h/ghy

\section{Radioactive Effluents in Savannah River Summary Report for 1997 (U)}

\section{Introduction}

The Nonproliferation Technology section (NTS), formerly Environmental Technology section (ETS), has conducted radiometric studies of Plant Vogtle since late 1986, seven months prior to its startup [ref 1]. This program has now been terminated as of May of this year, as support funding is no longer available. The present report presents the final 1997 measurements, as a closeout of this program of study.

Plant Vogtle has two 1100 MWe pressurized water reactors developed by Westinghouse. Unit 1 started commercial operations in June 1987, and Unit 2 began in May 1989. During powered operations, NTS routinely detected neutron-activated isotopes in controlled releases [refs 2-10] but all activities had been orders of magnitude below the DOE guide values [ref 11] and EPA/CFR levels [ref 12]. The Vogtle release data and the NTS measurements have tracked well over the past ten years. These very sensitive ultra low-level measurements of the radioactive effluents have been important to both institutions, as they could address abnormal trends before they became health and compliance concerns.

In early 1997, NTS continued to detect radioactive effluents in the river from SRS and Plant Vogtle. NTS ultra low-level radiometric measurement techniques were used in this work. In general, river samples were collected on ion exchange resins, concentrated further in the lab, and then counted in the 
Underground counting Facility at 735-A [ref 13]. Beginning in 1995, this study has only reported gamma spectrometry measurements, as the tritium analyses were transferred to another NTS facility that utilized very sensitive tritium gas proportional counting [ref 14]. The overall sampling/counting technique for gamma-ray analysis provides detection limits that are thousands of times lower than those routinely achievable. Also, an underwater NaI(Tl) detector at Hwy 301 Bridge provided continuous gamma monitoring of the Savannah River.

\section{Summary}

During early 1997, the radioactive effluents in the Savannah River were comparable to (or lower than) those observed during the earlier years of these studies, being orders of magnitude below DOE and EPA/CFR guide levels. Relative to SRS and Plant Vogtle, the upstream site at Shell Bluff and the downstream site at Hwy 301 Bridge were the only resin sampler sites still in service.

Vogtle associated activities were fairly low during early 1997, as was the case in 1996 when the largest activities occurred during June to August. Only ${ }^{60} \mathrm{Co}$, the dominant radionuclide from recent vogtle releases, was observed in early 1997. The maximum ${ }^{60} \mathrm{Co}$ observed was only $11 \mathrm{fCi} / \mathrm{L}$, whereas the previously dominant ${ }^{58} \mathrm{Co}$ was not detected and typically less than $2 \mathrm{fCi} / \mathrm{L}$. These Hwy 301 activities are projected to be an order of magnitude less than those just downstream of the outfall of Plant Vogtle, based on earlier measurements [ref 9].

SRS associated gamma activities were, for ${ }^{137} \mathrm{Cs}$, which were observed at levels consistent with known SRS sources. In early 1997 the maximum observed ${ }^{137} \mathrm{Cs}$ was $51 \mathrm{fCi} / \mathrm{L}$. As in 1996, both standard and isotope-specific resins were used for cesium collection and analysis, and the larger of the two resin values was adopted for conservatism.

\section{River sampling}

Samples were collected from the Savannah River at Shell Bluff, near the Vogtle outfall, and at Hwy 301 bridge. Bi-weekly resin samplers for river water concentrations were only located at Shell Bluff and Hwy 301 Bridge. A map of the sampling sites is given in Appendix A. Quarterly sediment samples were taken near the Vogtle outfall and at Hwy 301 Bridge.

The sampling philosophy relied on the data obtained from the earlier studies [refs 1-9] and the fact that no large-scale SRS reactor operations have occurred since 1988. Accordingly, Vogtle releases have been primarily dominated by reactor produced neutron activation products $\left({ }^{54} \mathrm{Mn},{ }^{58} \mathrm{Co}\right.$, etc), which are unlikely 
to have a current source from SRS. Most of the releases attributed to SRS are from earlier release sources (primarily $\left.{ }^{137} \mathrm{Cs}\right)$ that continue to contribute to the river. Earlier sampling [refs 1-9] had deployed resin samplers just above and below the Vogtle outfall to assure that the above distinction between Vogtle and SRS releases could be made. Should Plant Vogtle experience significant fuel failures incurring noticeable fission product releases (particularly ${ }^{137} \mathrm{Cs}$ ), resumption of such sampling in the vogtle vicinity would be strongly advised.

Resin and sediment samples were collected using methods detailed in the Vogtle pre-start study [ref 1]. Each resin concentrator sampler consists of $\approx 25 \mathrm{~g}$ of resin in a collector. Beginning in 1996, the collections of both the standard resin sampler and a ${ }^{137} \mathrm{Cs}-$ specific resin sampler were incorporated into the analyses. The samplers were in the river for two weeks, after which they were retrieved and returned to the lab. Sediment samples were scooped into a specially designed sampler pulled along the bottom of the river.

\section{Laboratory Measurements}

The resin concentrator samples provided the most comprehensive isotopic information. Each of these samples was dried and ashed, leaving a smaller volume and thus better counting geometry for the HPGe detector. Typically, two HPGe detectors, with ${ }^{60} \mathrm{Co}$ standard efficiencies of $20 \%$ and $25 \%$, were used in counting these samples; both are located in the Underground Counting Facility. Also, larger detectors with ${ }^{60} \mathrm{Co}$ standard efficiencies of $90 \%$ and $160 \%$ were occasionally used. (The 90\% HPGe includes an active/passive shield). Samples were counted overnight (or over the weekend) to assure good counting statistics for detecting low-level activities. The resulting $\mathrm{HPGe}$ gamma-ray spectra were analyzed using the GRABGAM code [ref 13] to yield the activity (fCi) of each isotope detected in the resin sample. The average isotopic concentration ( $\mathrm{fCi} / \mathrm{L}$ ) for the collection period was obtained by using empirical calibration data that relate the resin mass and collection time to the effective water volume (L).

Sediment samples were dried and transferred to 1-L Marinelli beakers for counting on the $20 \%$ and $25 \%$ HPGe detectors. The sample isotopic activities (fCi) from the gamma-ray analysis are divided by the dry weight ( $g$ ) of each sample to yield the corresponding concentrations ( $\mathrm{fCi} / \mathrm{g}$ ). 


\section{Underwater NaI(Tl) Measurements}

The underwater NaI(TI) detector operated from a floating platform anchored near Hwy 301 bridge. The unit has a 9" diameter by 4" long NaI(Tl) detector, four photo-multiplier tubes, and a high voltage/preamp unit - all contained in a waterproof stainless steel housing. The detector views its surroundings through a thin hemispherical dome.

The detector received operating power via a waterproof cable connected to a $\approx 25 \mathrm{~V}$ DC supply in the cabin of the pontoon boat. $A$ unit within the detector assembly boosted this voltage to about $1000 \mathrm{~V}$ for photo-tube operation. The AC-coupled detector signals were transmitted via the same cable to the cabin, where they were amplified and input to a multichannel analyzer.

Spectral data were collected on the multichannel analyzer, which utilized a COMPAQ 286 computer with an ACE MCA card from EG\&G ORTEC. Spectra were stored on floppy disk in sequenced 24-hr periods for 2-3 weeks. The disks were retrieved and analyzed at the laboratory. This detector system provided better time resolution ( 1 day) than the resin concentrator method (2 weeks), but its sensitivity was poorer by more than an order of magnitude [refs 15,16$]$.

The performance of the underwater NaI detector during 19871994 illustrates that it has tracked the notable vogtle releases quite reliably by its detection of ${ }^{58} \mathrm{Co}$ [ref 15,16$]$. By contrast, the NaI detector did not readily obserye sRs effluents during this period, as concentrations of the dominant ${ }^{137}$ Cs of SRS river effluents were below the detection limit for the NaI detector.

During 1996, the underwater NaI was re-outfitted with replacement photo-multiplier tubes, as the detector had failed in October of 1995 due to a line surge following a power outage by Planters Electric Co. The available replacement tubes did not yield as good resolution, but the detector was appraised as adequate to detect releases that were a few orders of magnitude below legal guidelines (see Table 6 ). 


\section{Results}

137 The resin sampler analyses continued to indicate ${ }^{60} \mathrm{Co}$, and ${ }^{137} \mathrm{Cs}$, but no ${ }^{58} \mathrm{Co}$, which were the most significant gamma-emitting radionuclides detected in the earlier studies [refs 2-10]. The early 1997 results for these isotopes are given in Tables 1-3, along with plots in Figures $1-3$. Table 3 includes ${ }^{137} \mathrm{Cs}$ as predicted by the standard resin, the ${ }^{137} \mathrm{Cs}-$ specific resin, and their conservative maxima; Figures $3 A, 3 B$, and $3 C$ are the corresponding plots.

other measurements of ${ }^{58} \mathrm{Co},{ }^{60} \mathrm{Co}$, and ${ }^{137} \mathrm{Cs}$ are also being performed in 1997 by NTS [ref 14]. For these measurements, no ${ }^{58} \mathrm{Co}$ or ${ }^{58} \mathrm{Co}$ was detected on the resin fraction, but there was trace evidence of ${ }^{60} \mathrm{Co}$ on one of two particulate fractions that have been counted. However, a good quantitative comparison with the resin samplers of the present work was not afforded by the early 1997 results, as no significant ${ }^{60} \mathrm{Co}$ had been released by Plant Vogtle. The absence of particulate fraction counting in 1996 samples had been posited as a reason for why ${ }^{60}$ Co had not been detected in these other measurements [ref 10]. By contrast, both measurements continued to detect ${ }^{137} \mathrm{Cs}$, which had been shown to be in reasonable quantitative agreement in 1996 [ref 10].

Various other manmade gamma-emitting radionuclides of Table 4 were not detected in early 1997, although they had been detected earlier. The 1997 tabulations correspond to Hwy 301 Bridge, in contrast to similar earlier tabulations for measurements below the Vogtle outfall. Consequently, the 1997 data does not exhibit as many Vogtle isotopes as observed in earlier years due to the less optimum sampling location.

Sediments were analyzed for ${ }^{58} \mathrm{Co},{ }^{60} \mathrm{Co}$, and ${ }^{137} \mathrm{Cs}$ to appraise whether significant deposition is occurring during the transport of these isotopes in river water. The corresponding results are shown in Table 5 .

Data for the underwater NaI(TI) detector are presented in Figure 4, which is an isometric plot of count rate vs gamma energy and date. Gaps in the data exist in late January and part of February, due to a power outage and a NIM bin failure. During this interval, replacement of the amplifier resulted in eliminating the spurious peak in the $1100 \mathrm{keV}$ vicinity, leaving only the $1120 \mathrm{keV}$ peak of Bi-214. Unfortunately, the replacement amplifier caused some interferences for the peaks below $400 \mathrm{keV}$; however, this had little impact on the ability to detect the major radionuclides from SRS $\left({ }^{137} \mathrm{Cs}\right)$ and Vogtle $\left({ }^{58} \mathrm{Co}\right.$ and $\left.{ }^{60} \mathrm{Co}\right)$. 


\section{Discussion}

\section{River Water Activity Levels}

In early 1997; the maximum reported manmade radioactivities in the Savannah River were at Hwy 301 Bridge, but these do not represent the highest levels in the river for each isotope. The earlier studies [refs 1-9] utilized resin samplers $0.1 \mathrm{mi}$ downstream of the vogtle outfall, indicating neutron-activated isotope levels that were over an order of magnitude larger than those observed at Hwy 301 Bridge [ref 9]. This is apparent from Table 6, which compares the maximum reported levels of early 1997 with those of earlier years. A more realistic comparison is effected by increasing the $1997{ }^{60} \mathrm{Co}$ levels by an order of magnitude (factor of 10). Such a comparison indicates that the 1997 maximum ${ }^{60} \mathrm{Co}$ is not significantly different from those of 1995-96; unfortunately, the 1997 resin measurements (Hwy 301 Bridge) were not sensitive enough to detect/compare gamma activities of other isotopes in the table. The ${ }^{137} \mathrm{Cs}$ maximum occurred at Hwy 301 Bridge and thus may be compared directly.

The earlier studies imply that sRs effluents dominate the observed ${ }^{137} \mathrm{Cs}$, and that Vogtle is the primary source of the other manmade gamma-emitting radionuclides as they are all neutron activation products. Although the early 1997 results are consistent with this pattern, they do not provide proof-positive confirmation. Indeed, the 1995 report [ref 9] noted evidence of pinhole leaks in vogtle fuels which yielded a ${ }^{137} \mathrm{Cs}$ concentration of $45 \mathrm{fCi} / \mathrm{L}$ in a resin sample just below Vogtle. Such Vogtle levels are comparable to the 1997 maximum of $51 \mathrm{fCi} / \mathrm{L}$ and are not currently distinguished from SRS sources. Proof-positive distinction between SRS and Vogtle contributions to the Savannah River can only be determined by reinstituting the resin samplers above and below the vogtle outfall.

\section{Sediment Activity Levels}

The sediment samples exhibited ${ }^{137} \mathrm{Cs}$, but ${ }^{58} \mathrm{Co}$ and ${ }^{58} \mathrm{Co}$ were not observed in early 1997, as indicated in Table 6. Overall activities observed in 1997 are comparable to those observed in earlier years [refs 2-10]. The largest ${ }^{137} \mathrm{Cs}$ activity continued to be observed at Hwy 301 Bridge, having concentration of $78 \mathrm{pCi} / \mathrm{kg}$ for the only measurement in early 1997.

\section{Underwater NaI}

The underwater NaI(TI) detector at Hwy 301 Bridge did not produce sufficient data to examine ${ }^{58} \mathrm{Co}$ as had been done in the past [refs $2-8,15,16]$. Indeed, the isometric plot of Figure 4 only exhibits activities from natural backgrounds. Although the detector will neeci to be thoroughly refurbished to achieve sufficient resoluticin for detecting ${ }^{58} \mathrm{Co}$ and other manmade 
isotopes at levels comparable to the typical background, these isotopes are still detectable at levels a few orders of magnitude below the guide values of Table 6 .

\section{Drinking water Guides}

Table 6 compares the maximum-detected river concentrations with the DOE guide limits for drinking water. [ref 11] along with similar EPA/CFR guide limits [ref 12]. All concentrations are well below these guide limits. Furthermore, the table compares the maximum concentrations in 1997 with those of earlier years; however, as explained above, the 1997 values should be increased by an order of magnitude to better represent the actual (as opposed to measured) maxima. All radionuclide concentrations are well below DOE and EPA/CFR guides for drinking water, as shown in the table.

\section{Termination of study}

These studies were terminated by early May of 1997 due to insufficient funding. Subsequently, all existing resin and sediment samples have been counted, analyzed, and presented in this report. All spectra collected on the underwater NaI detector have also been analyzed and presented herein. In mid-May this detector was removed from service at Hwy 301 Bridge and returned to NTS facilities at SRTC for storage and eventual refurbishing.

The entire study has spanned the 1986-1997 interval and has been completely documented with this final report and its references, which also includes data on the mouths of SRS effluent streams to the river [ref 17]. At the same time, the documentation might be appended to include all earlier ${ }^{134} \mathrm{Cs}-$ specific resin data, as was the case beginning in 1996. The pre$1996{ }^{137} \mathrm{Cs}$ results were based on the standard resin samplers alone and thus are about $40 \%$ low on average [ref 10]. Since the ${ }^{137} \mathrm{Cs}$ levels have been decreasing gradually and smoothly over the years, a constant $40 \%$ correction to all the earlier ${ }^{137} \mathrm{Cs}$ data is probably sufficient without correcting individual cases with their ${ }^{13} \mathrm{Cs}-$ specific resin results. 


\section{Acknowledgements}

The author. thanks those individuals who supported this final work. Shan Sundaram of Plant Vogtle continued to provide useful information on their releases. Scott Reboul contributed useful discussions concerning his results on Savannah River measurements. Shirley Patterson analyzed all resin and sediment samples in the Underground counting Facility, and entered the results into electronic spreadsheets for final evaluation. Sharon Redd prepared the resin samples for counting, including weighing, ashing, and encapsulation. Sara Green conducted sample prep for the studies by Scott Reboul. R.R. Penix, R.J. Roseberry, and A.B. Antonicelli conducted the river sampling operations. Ron Johnson and Wanda Matthews assisted with the underwater NaI detector operations.

Many others have supported these studies in earlier years, and these are acknowledged in the earlier reports [refs 1-10]. 


\section{References}

1. R.A. Sigg and W.G. Winn, Pre-operational Radio-Environmental Studies of Plant Vogtle, WSRC-RP-89-161, MaY 1, 1989.

2-10 W.G. Winn, Radioactive Effluents in the Savannah River Summary Report for:

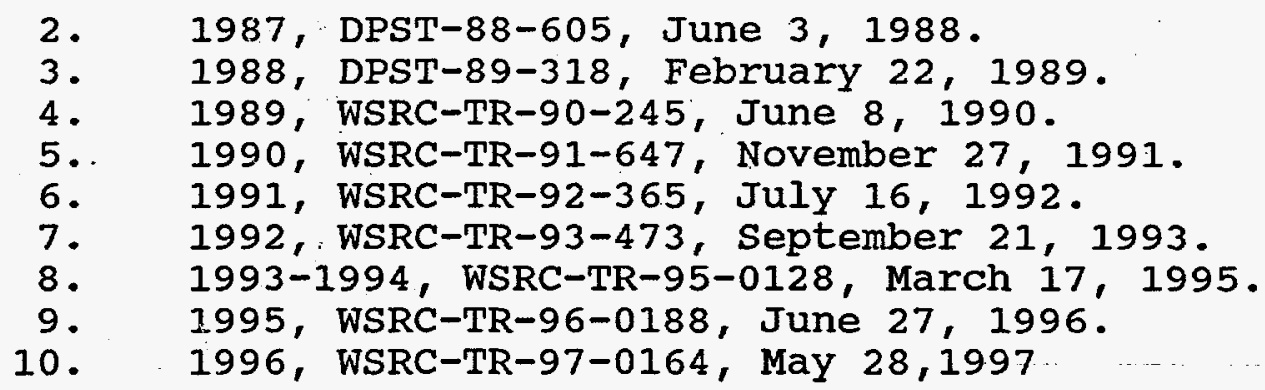

11. Department of Energy Order DOE 5484.1 (Draft 1986).

12. Savannah River Site Environmental Report for 1993, WSRC-TR94-075, Appendix D.

13. W.G. Winn, W.W. Bowman, and A.L. Boni, Ultra-clean Underground Counting Facility for Low-Level Environmental Samples, DP-1747, September 1987.

14. S.H. Reboul, provided from 1997 data for NTS analytical support of EMS (See memo attached in Appendix B).

15. W.G. Winn and Shan Sundaram, "Verification of Reactor Effluent Releases with an Underwater NaI Detector", Proceedings of ANS Topical Meeting on Environmental Transport and Dosimetry (Charleston, SC, September 1-3, 1993), pp 101-103.

16. W.G. Winn, "Environmental Measurements at the Savannah River Site with Underwater Gamma Detectors", Journal of Radioanalytical Chemistry 194, 345-350 (1995).

17. W.G. Winn, "Summary of Savannah River Data 1987-1995", SRTCETS-96-334 (October 17, 1996). 
Tables 1\&2. Co-58 and co-60 Concentrations in 1997

(Values in $\mathrm{fCi} / \mathrm{L})^{a}$

\begin{tabular}{|c|c|c|c|c|c|}
\hline \multirow[b]{2}{*}{ Date } & \multirow[b]{2}{*}{ Plat $x$} & \multicolumn{2}{|c|}{$C a-5 B$} & \multicolumn{2}{|c|}{$C u-60$} \\
\hline & & $\begin{array}{l}\text { Shell Bluff } \\
\text { fCi } / \mathrm{L}\end{array}$ & $\begin{array}{l}\text { H301 Bridge } \\
\text { fCi } / \mathrm{L}\end{array}$ & $\begin{array}{l}\text { Strell bluff } \\
\text { fCi } / \mathrm{L}\end{array}$ & $\begin{array}{l}\text { H3OL Bridge } \\
\text { fCi/L }\end{array}$ \\
\hline $12 / 17-01 / 07 / 97$ & - & -5.85 & -8.32 & -4.40 & 9.90 \\
\hline $01 / 07-01 / 21 / 97$ & 3 & -1.09 & -1.90 & -0.80 & 3.70 \\
\hline $01 / 21-02 / 04 / 97$ & * & -3.84 & -6.87 & $-4: 20$ & 9.50 \\
\hline $02 / 04-02 / 18 * / 97$ & $F$ & -0.78 & -1.60 & -0.60 & 2.60 \\
\hline $02 / 18 x-03 / 04 / 97$ & \pm & $\quad-3.55$ & -1.82 & -3.00 & 3.50 \\
\hline $03 / 04-03 / 18 / 97$ & $H$ & -4.44 & -1.09 & -3.50 & -0.90 \\
\hline $03 / 18-04 / 01 / 97$ & 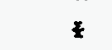 & -2.80 & $-1.45^{\circ}$ & -2.70 & 2.90 \\
\hline $04 / 01-04 / 15 / 97$ & $A$ & -3.20 & -1.80 & -2.90 & 11.00 \\
\hline $04 / 15-04 / 29 / 97$ & $\mp$ & -4.03 & -4.33 & -3.00 & 2.90 \\
\hline
\end{tabular}

a) Respective Co-58 and co-60 counting errors are estimated at $\leq 0.82 \mathrm{~V}^{1 / 2}$ and $\leq 0.75 \mathrm{~V}^{1 / 2}$ where $\mathrm{V}$ is entry value. Values with minus(-) are minimum detectable amounts or MDAs.

Table 3. Cs-137 Concentrations in 1997

(Values in $\mathrm{fCi} / \mathrm{L})^{\mathrm{a}}$

\begin{tabular}{|c|c|c|c|c|c|c|c|}
\hline \multirow[b]{2}{*}{ Date } & \multirow[b]{2}{*}{ Plot $x$} & \multicolumn{2}{|c|}{ Standard Resin } & \multicolumn{2}{|c|}{ Isutupe Specific Resin } & \multicolumn{2}{|c|}{ Haximur of Resins } \\
\hline & & $\begin{array}{l}\text { Shell Bluff } \\
\text { fCi } / \mathrm{L}\end{array}$ & $\begin{array}{l}\text { H301 Bridge } \\
\mathrm{fE \textrm {i }} / \mathrm{L}\end{array}$ & $\begin{array}{l}\text { Shell Bluff } \\
\mathrm{fCi} / \mathrm{L}\end{array}$ & $\begin{array}{l}\text { H301 Eridge } \\
\text { fCi } / L\end{array}$ & $\begin{array}{l}\text { Shell Eluff } \\
\mathrm{fCi} / \mathrm{l}\end{array}$ & $\begin{array}{l}\text { H301 Eridge } \\
\text { fCi } / 1\end{array}$ \\
\hline $12 / 17-01 / 07 / 97$ & $*$ & 5.67 & 23.58 & 1.55 & 45.52 & 5.67 & 45.52 \\
\hline $01 / 07-01 / 21 / 97$ & $\mathbf{I}$ & 5.13 & 7.79 & 11.13 & 13.1 & 11.03 & 13.10 \\
\hline $01 / 21-02 / 04 / 97$ & \pm & 5.50 & 16.58 & 12.60 & 50.81 & 12.60 & 50.81 \\
\hline $02 / 04-02 / 18 * / 97$ & $F$ & 3.01 & 5.83 & 11.41 & 42.68 & 11.41 & $4 \overline{2} .69$ \\
\hline $02 / 18 z-03 / 04 / 97$ & $*$ & -1.74 & 6.21 & 14.60 & 36.56 & 14.60 & 36.56 \\
\hline $03 / 04-03 / 18 / 97$ & $H$ & 3.63 & 7.31 & 10.54 & $31.4 \mathrm{~B}$ & 10.54 & 31.48 \\
\hline $03 / 18-04 / 01 / 97$ & 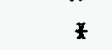 & 2.73 & 6.25 & 14.43 & 29.78 & 14.43 & 29.78 \\
\hline $04 / 01-04 / 15 / 97$ & $A$ & 3.29 & 11.24 & 19.51 & 36.94 & 18.51 & 36.94 \\
\hline $04 / 15-04 / 29 / 97$ & * & 2.68 & 7.84 & 12.06 & 33.87 & 12.06 & 33.87 \\
\hline
\end{tabular}

a) Counting error estimated at $\leq 0.58 \mathrm{~V}^{1 / 2}$ where $\mathrm{V}$ is entry value. Values with minus(-) are minimum detectable amounts or MDAs. 
Table 4. Relative Isotopics in Savannah River During $1997^{a, b}$

(Sample site at Hwy 301 Bridge)

\begin{tabular}{|c|c|c|c|c|c|c|c|c|c|c|c|}
\hline \multirow[t]{2}{*}{ Date } & \multirow[t]{2}{*}{ Plot $x$} & $c 0-60$ & \multicolumn{6}{|c|}{ Isotopics $\%$ of Ca-60 Activity at Hay 301 Bridoge } & \multirow[b]{2}{*}{ Nth-95 } & \multirow[b]{2}{*}{$2 r-95$} & \multirow[b]{2}{*}{$s-137$} \\
\hline & & $\mathrm{fCi} / \mathrm{L}$ & {$[\mathrm{Cr}-51$} & $H n-54$ & {$[a-57$} & {$[0-58$} & $\mathrm{Fe}-5 \mathrm{~F}$ & {$[0-60$} & & & \\
\hline $12 / 17-01 / 07 / 97$ & * & 9.90 & -- & -- & -- & -84.29 & - & 100.00 & -- & -- & 459.80 \\
\hline $01 / 07-01 / 21 / 97$ & $J$ & 3.70 & - & -- & -- & -51.44 & -- & 100.00 & - & - & 354.05 \\
\hline $01 / 21-02 / 04 / 97$ & ¥ & 9.50 & -- & -- & - & -72.24 & - & 100.00 & -- & -- & 534.84 \\
\hline $02 / 04-02 / 18 * / 97$ & $F$ & 2.60 & - & -- & -- & -61.54 & -84.62 & 100.00 & - & -- & 1641.54 \\
\hline $02 / 18 *-03 / 04 / 97$ & * & 3.50 & -- & -- & -- & -52.27 & - & 100.00 & -- & -- & 1044.57 \\
\hline $03 / 04-03 / 18 / 97$ & $n$ & -0.90 & -- & -- & -- & -116.00 & -- & -100.00 & - & -- & 3497.78 \\
\hline $03 / 18-04 / 01 / 97$ & * & 2.90 & -- & -- & -- & -525.00 & - & 100.00 & - & -- & 1026.90 \\
\hline $04 / 01-04 / 15 / 97$ & A & 11.00 & -- & - & -- & -16.39 & -- & 100.00 & - & -- & 335.82 \\
\hline $04 / 15-04 / 29 / 97$ & \# & 2.90 & -- & -- & -- & -151.16 & -- & 100.00 & -- & -- & 1167.93 \\
\hline
\end{tabular}

* For Shell Bluff replace $2 / 18$ with $2 / 25$

a) All values are relative activities on resin sample, except for ${ }^{137} \mathrm{Cs}$, which is uses conservative maximum of Table 3 .

b) MDA values are denoted with a minus(-) sign for all entries. 
Table 5. Sediment concentrations in $1997^{\circ}$

$$
\text { (Values in } \mathrm{fCi} / \mathrm{g}=\mathrm{pCi} / \mathrm{kg})
$$

\begin{tabular}{|c|c|c|c|c|c|}
\hline \multirow[t]{2}{*}{ Isotope } & \multirow[t]{2}{*}{ Date } & \multicolumn{3}{|c|}{ Vogtle vicinity } & \multirow{2}{*}{$\begin{array}{l}\text { Hwy } 301^{b} \\
-32.0 \mathrm{mi}\end{array}$} \\
\hline & & $+0.3 \mathrm{mi}$ & $0.0 \mathrm{mi}$ & $-0.1 \mathrm{mi}$ & \\
\hline${ }^{58} \mathrm{Co}$ & $\begin{array}{r}03 / 18 / 97 \\
Q 2 / 97 \\
Q 3 / 97 \\
Q 4 / 97\end{array}$ & $\begin{array}{c}<6.0 \\
- \\
-\end{array}$ & $\begin{array}{c}<10.0 \\
- \\
- \\
-\end{array}$ & $\begin{array}{c}<6.4 \\
- \\
- \\
-\end{array}$ & $\begin{array}{c}<8.3 \\
- \\
-\end{array}$ \\
\hline${ }^{60} \mathrm{Co}$ & $\begin{array}{r}03 / 18 / 97 \\
Q 2 / 97 \\
Q 3 / 97 \\
Q 4 / 97\end{array}$ & $\begin{array}{c}<4.5 \\
- \\
- \\
-\end{array}$ & $\begin{array}{c}<8.4 \\
- \\
-\end{array}$ & $\begin{array}{c}<5.5 \\
- \\
- \\
-\end{array}$ & $\begin{array}{c}<6.8 \\
- \\
- \\
-\end{array}$ \\
\hline${ }^{137} \mathrm{Cs}$ & $\begin{array}{r}03 / 18 / 97 \\
Q 2 / 97 \\
Q 3 / 97 \\
Q 4 / 97\end{array}$ & $\begin{array}{c}8.9 \pm 1.7 \\
- \\
- \\
-\end{array}$ & $\begin{array}{c}11.5 \pm 3.0 \\
- \\
-\end{array}$ & $\begin{array}{c}10.8 \pm 1.8 \\
- \\
-\end{array}$ & $\begin{array}{c}77 \cdot 7 \pm 3 \cdot 1 \\
- \\
- \\
-\end{array}$ \\
\hline
\end{tabular}

(a) Measurements program terminated $Q 2 / 97$.

(b) Miles are measured upstream of Vogtle outfall. 
Table 6. Comparison of Maximum 1987-1997 Levels with Guides for Drinking water

All measured levels are from samples $0.1 \mathrm{mi}$ downstream of Vogtle outfall unless specified otherwise.

Isotope

$$
\text { Maximum Concentration (pCi/L) }
$$

1987-92 1993-94 1995-96 a $^{1997}$ (to 4/29) DOE Guide EPA/CFR $^{\mathrm{b}}$

$\begin{array}{ccccccr}{ }^{3} \mathrm{H} & 47,300^{\mathrm{d}} & 64,000^{\mathrm{d}} & 2300^{\mathrm{e}} & 1600^{\mathrm{e}} & 2,000,000 & 20,000 \\ { }^{51} \mathrm{Cr} & 3.7 & 1.0 & <0.01 & <0.01^{\mathrm{e}} & 1,000,000 & 6000 \\ { }^{54} \mathrm{Mn} & 0.61 & 0.17 & 0.20 & <0.01^{\mathrm{e}} & 50,000 & 300 \\ { }^{57} \mathrm{Co} & 0.02 & 0.03 & 0.006 & <0.003^{\mathrm{e}} & 100,000 & -- \\ { }^{58} \mathrm{Co} & 16.8 & 1.81 & 0.46 & <0.01^{\mathrm{e}} & 40,000 & 9000 \\ { }^{59} \mathrm{Fe} & 0.49 & 0.06 & <0.01 & <0.01^{\mathrm{e}} & 20,000 & 200 \\ { }^{60} \mathrm{Co} & 0.49 & 0.42 & 1.31 & 0.11^{\mathrm{e}} & 5,000 & 100 \\ { }^{95} \mathrm{Nb} & 0.50 & 0.10 & 0.02 & <0.01^{\mathrm{e}} & 40,000 & 300 \\ { }^{95} \mathrm{Zr} & 0.23 & 0.05 & 0.01 & <0.01^{\mathrm{e}} & 60,000 & 200 \\ { }^{137} \mathrm{Cs} & 0.39^{\mathrm{e}} & 0.07^{\mathrm{e}} & 0.08^{\mathrm{e}} & 0.05^{\mathrm{e}} & 3,000 & 200\end{array}$

a) Below Vogtle data thru September 1995 (details - refs 9,10).

b) DOE 548.4.1 (details - ref 11).

c) See reference 12, which shows that higher levels are being proposed for some of the above values.

d) Maximum value at Vogtle outfall is high relative to EPA/CFR level based on an annual dose of $4 \mathrm{mrem}$, but the overall annual average at this location is well below EPA/CFR level. Also the river significantly dilutes these outfall levels.

e) Value at Highway 301 Bridge. For ${ }^{58} \mathrm{Co}_{3}$ and ${ }^{60} \mathrm{Co}$, projected values at Vogtle are $\geq 10 x$ higher. ( ${ }^{3} \mathrm{H}$ from $\left.\operatorname{Ref} 14\right)$. 


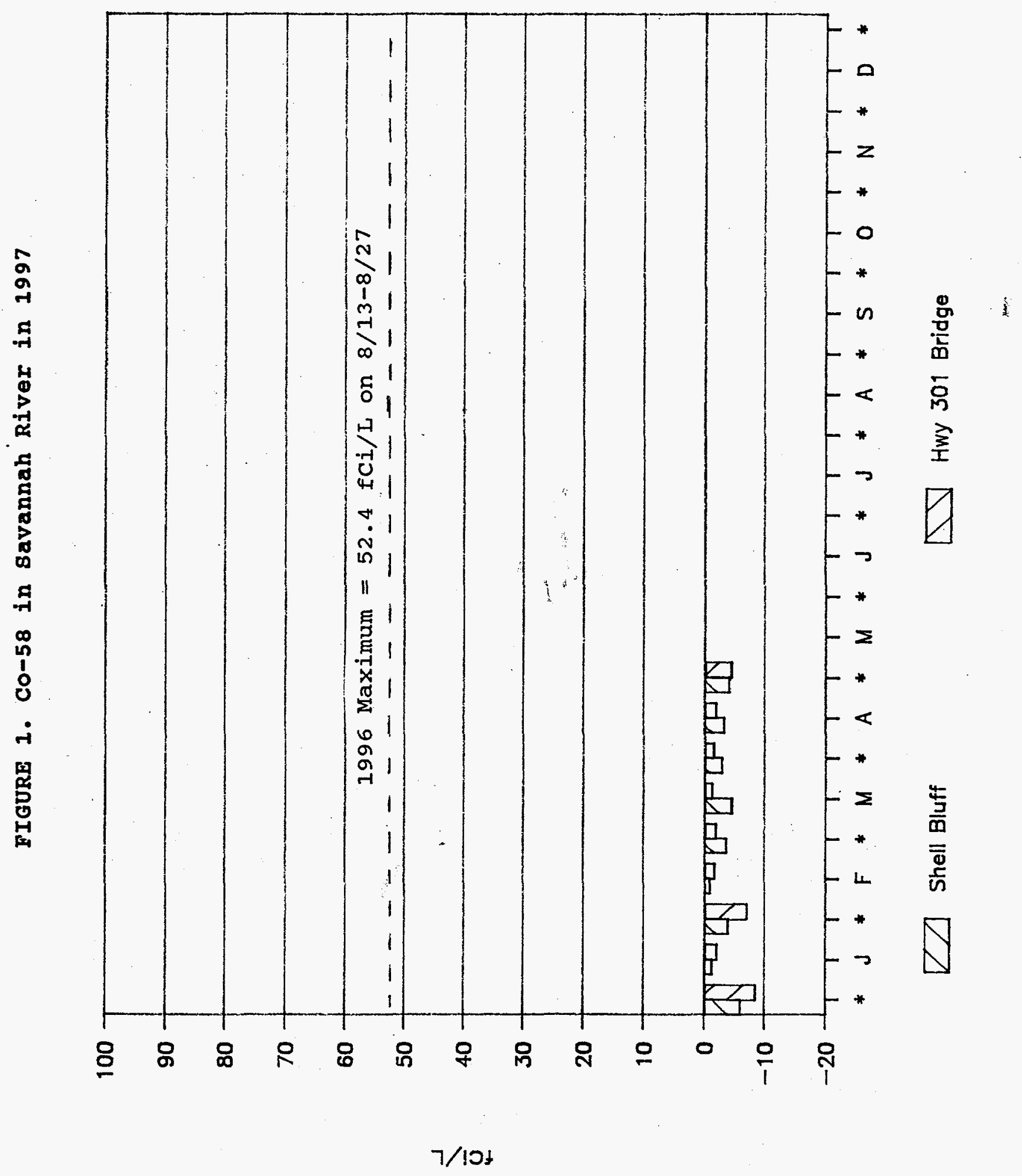




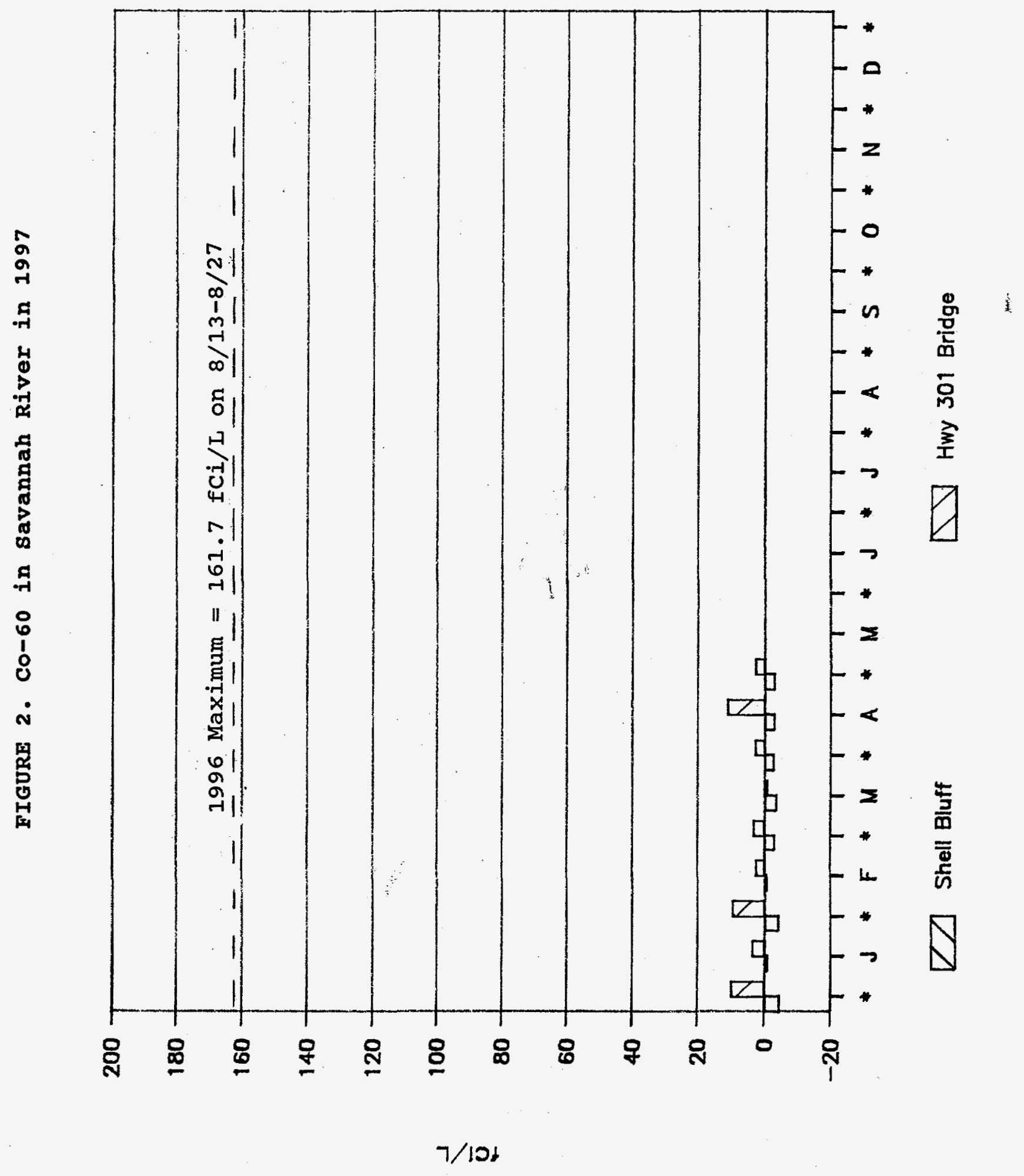




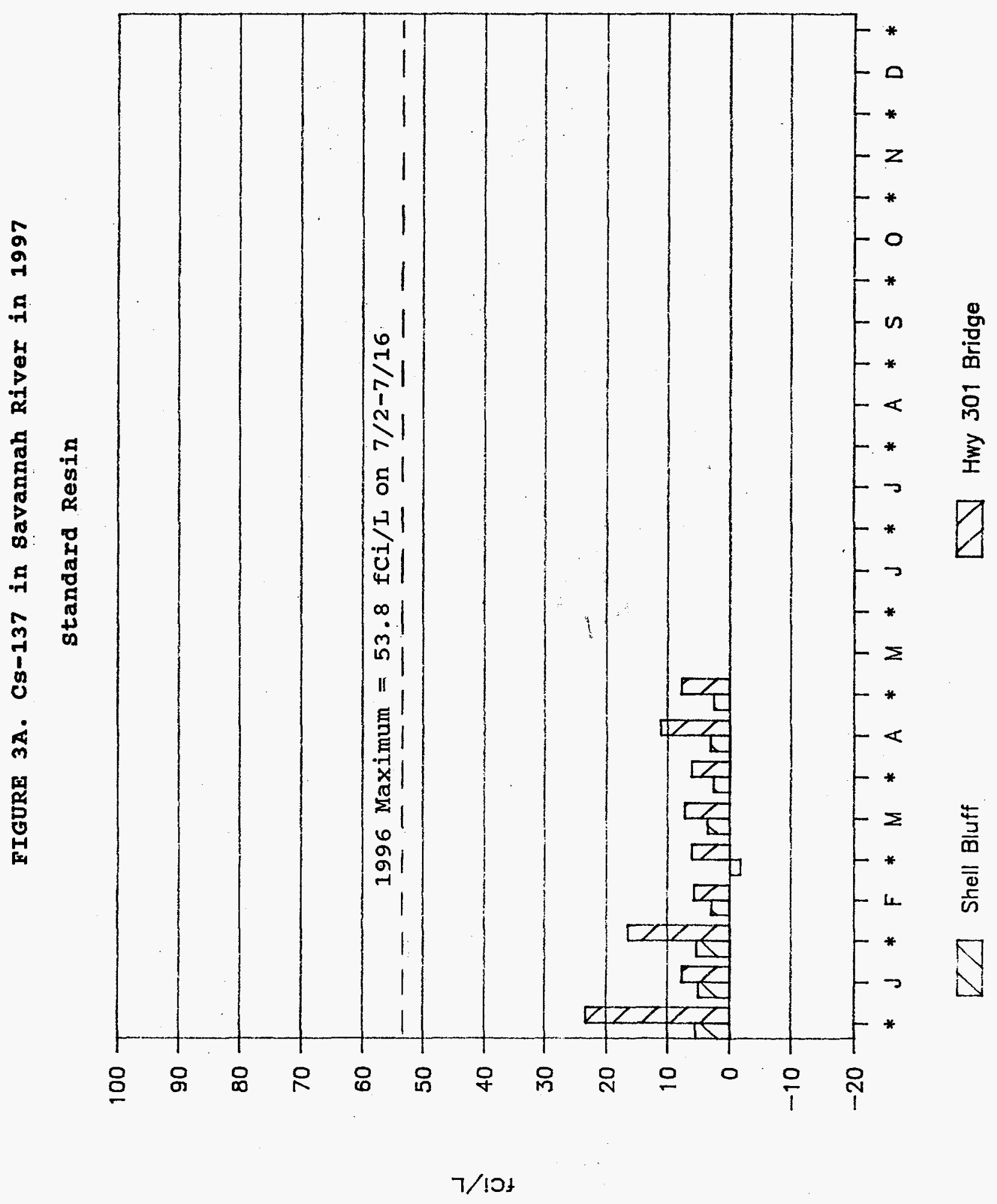




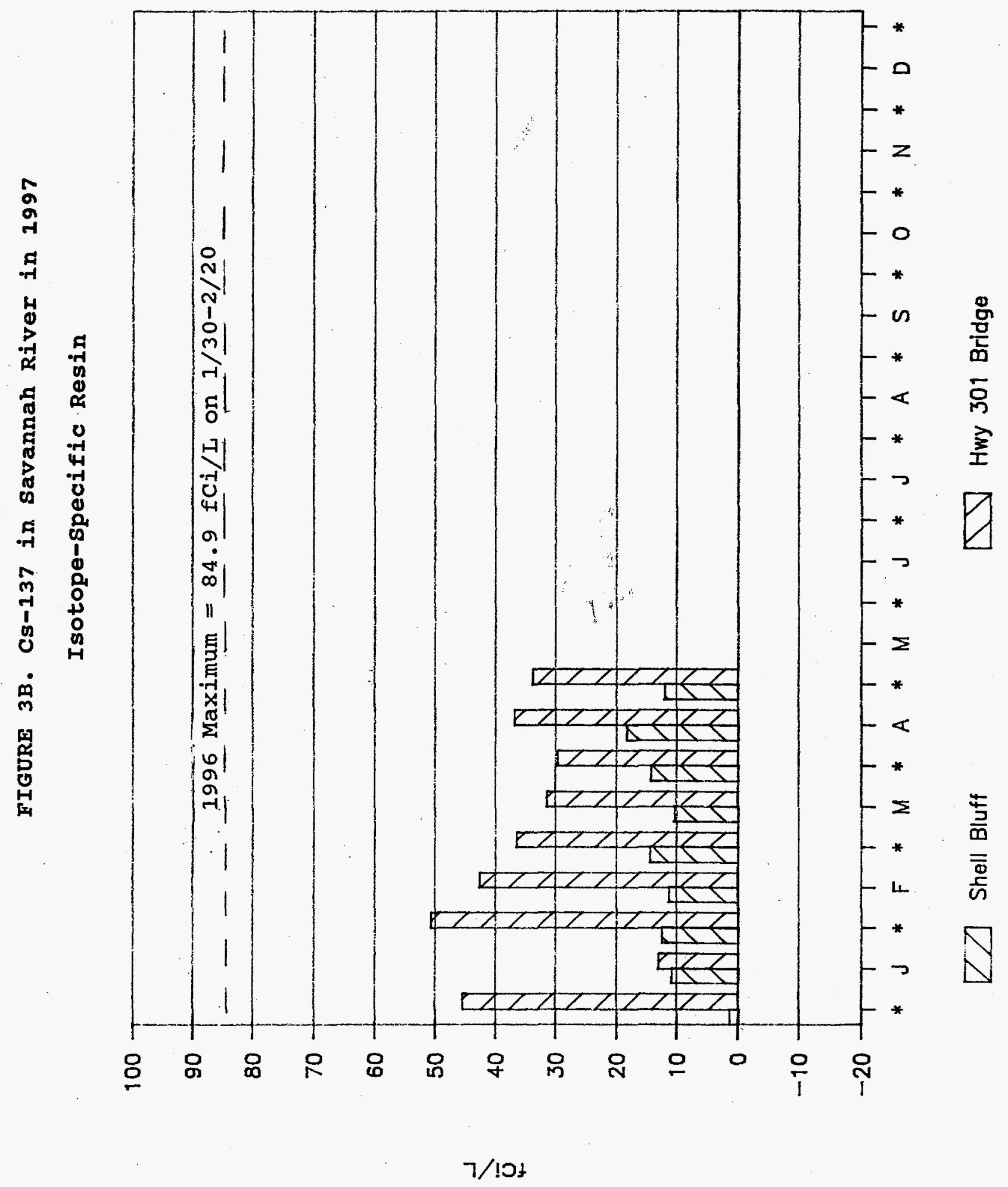




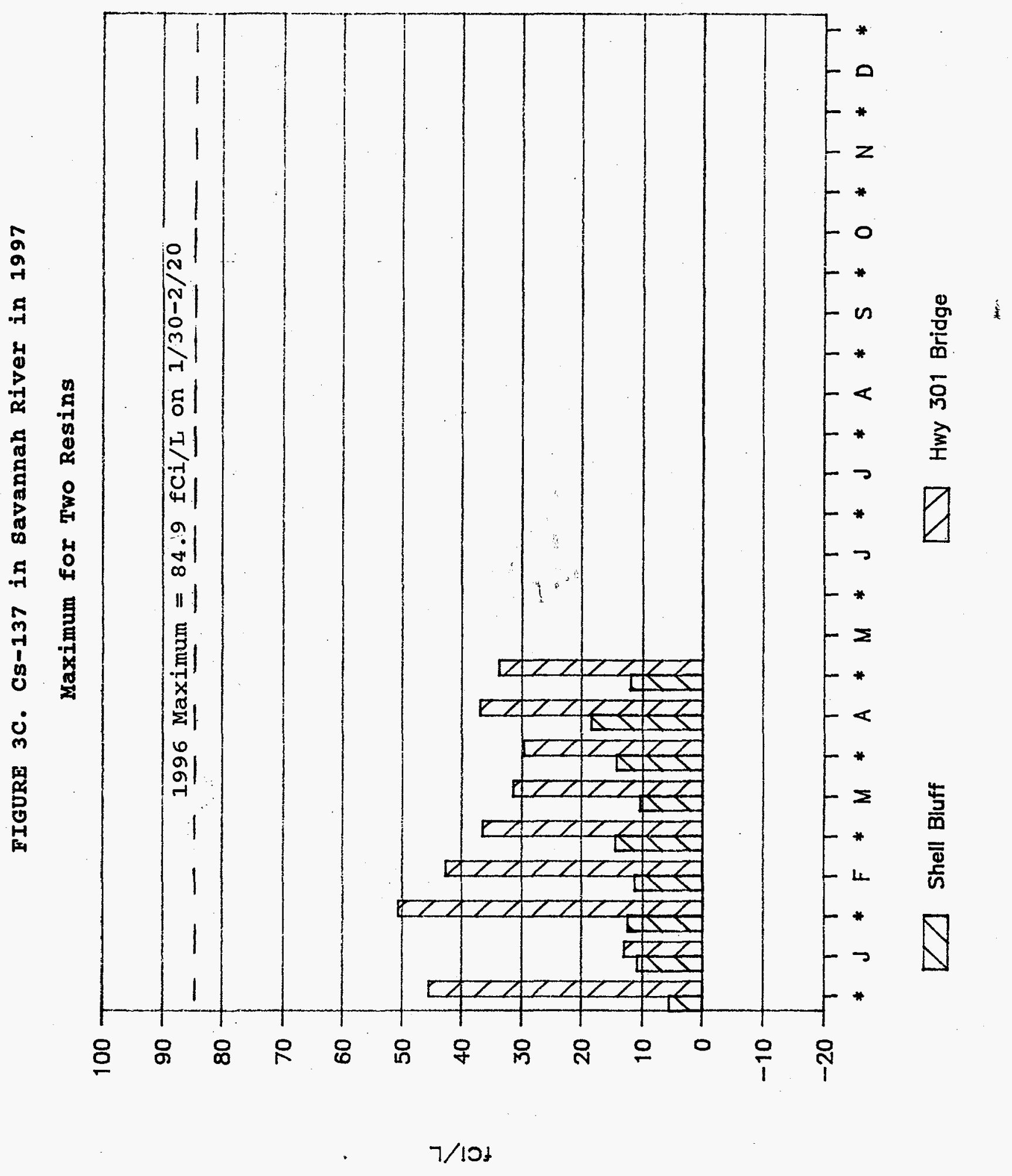




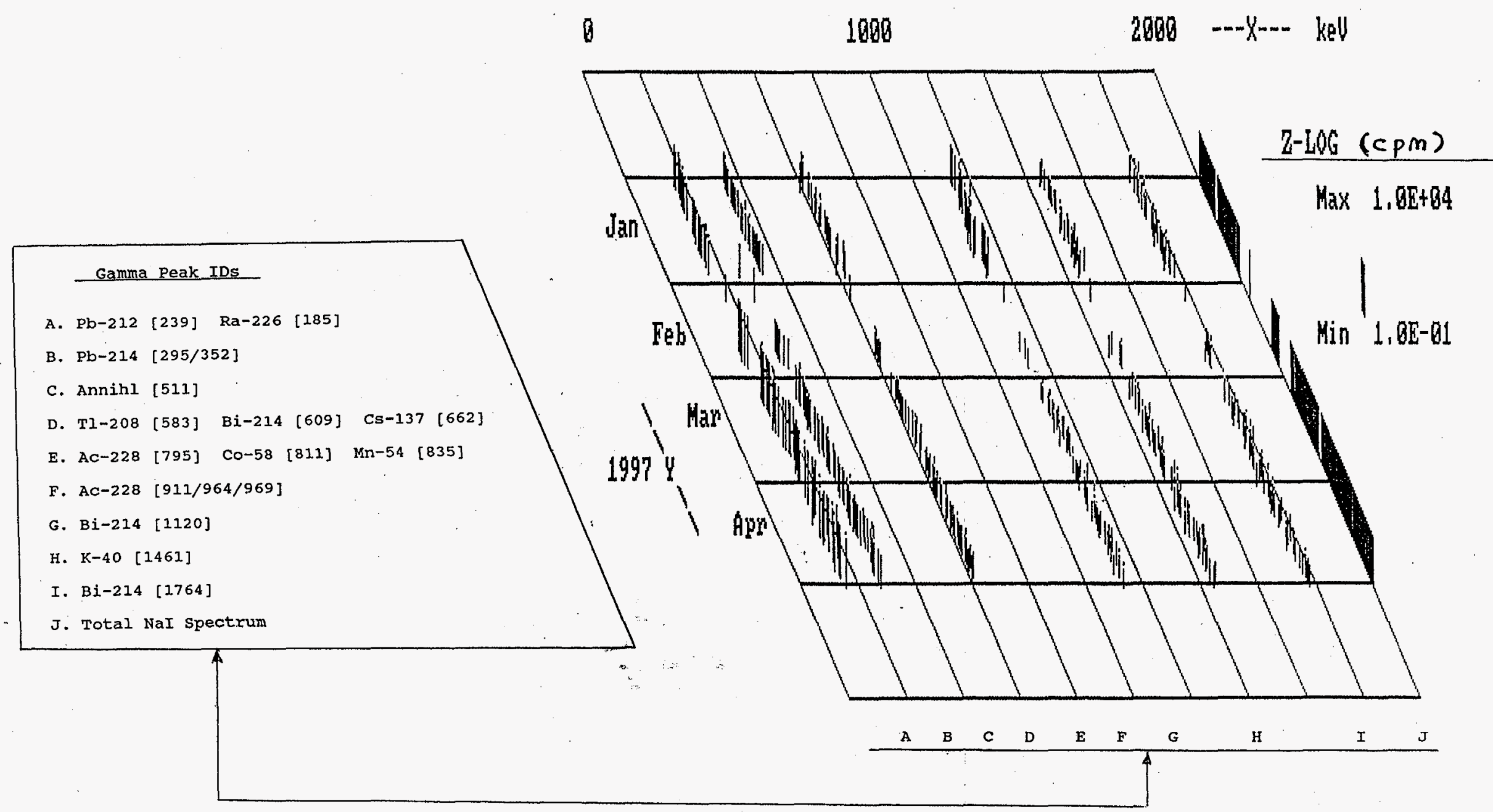

FIGURE 4. Results for Underwater NaI Detector at Hwy 301 Bridge 
Appendix A. Map of Sample Locations

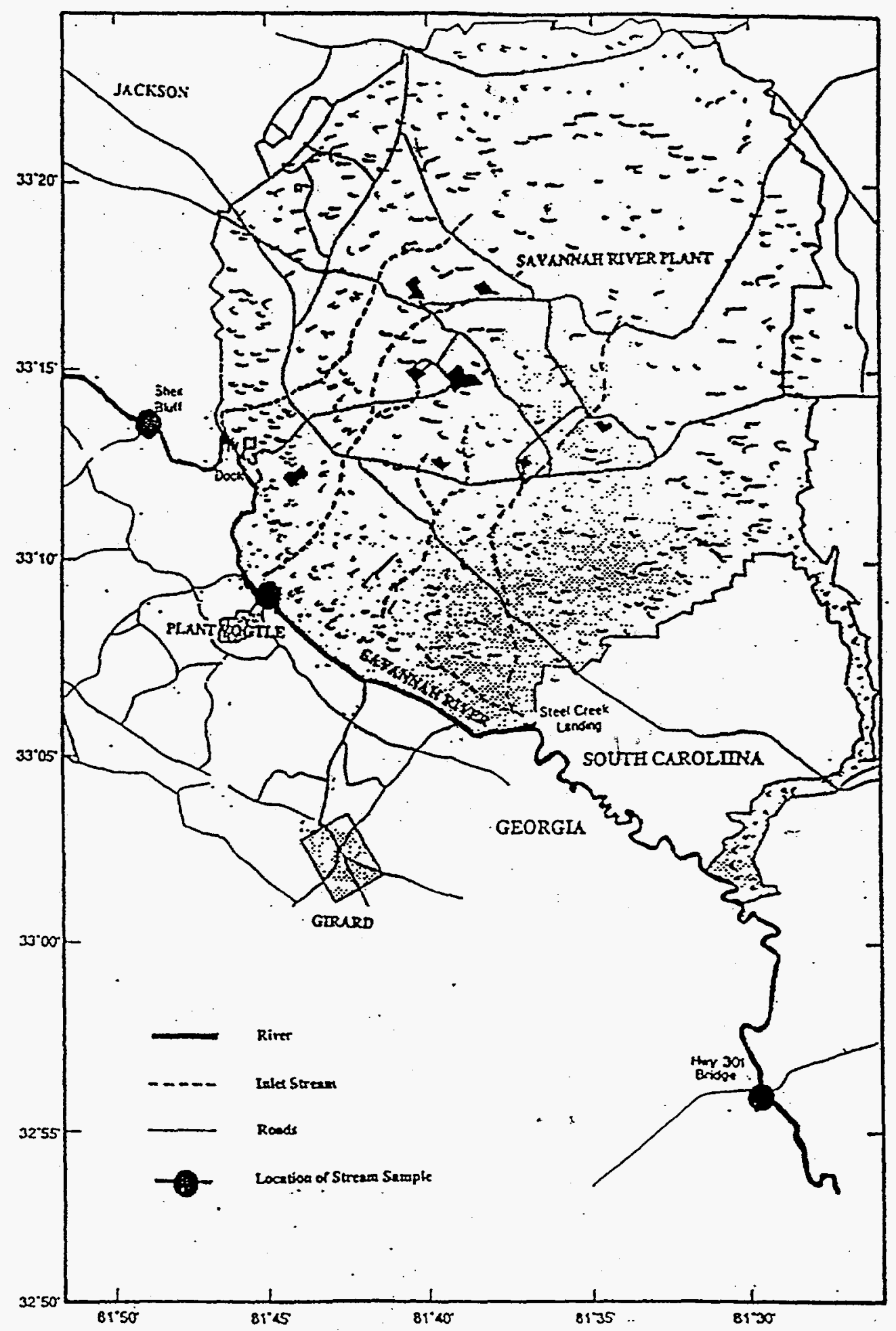


Appendix B. CC-Mail Memo on Tritium Data

Author: Scott Rebóul at SRCCA08

Date: $6 / 17 / 97$ 9:37 AM

Priority: Normal

TO: Willard Winn at SRCCA09

CC: William Emel at SRCCAIl

Subject: $\mathrm{H}-3$ in surface water from the Savannah River at Hwy 301

Bill, you asked what was the highest $\mathrm{H}-3$ concentration seen at HwY 301 between the months of January and April 1997. The high was $1.59 \pm$

$0.08 \mathrm{pCi} / \mathrm{mL}$, determined for a biweekly sample composited from 12/31/96 to $1 / 14 / 97$.

scott 